
Neither the United States Government nor any asency thereof, nor any of their employees, makes any wartanty, expresss or implied, or assumes any legal liability or ress, nnsibility tor the accuract,


represents that its use would not infininge privately ouned
commercial product, process, or service by trade name, trademark, manufacturer, or otherwise, does not necessarily constitute or imply its endorsement, recommendation, or favoring by the United States Government or any agency thereof. The views and opinions of authors expressed herein do not

SAND 80-0965

$$
\text { CONF-801048--5 }
$$

\title{
STABILITY AND COMPATIBILITY STUDIES
}

WITH THE INORGANIC EXPLOSIVE

2-(5-Cyanotetrazolato) pentaamminecobalt(III) Perchlorate (CP) *

T. M. Massis, P. K. Morenus,

D. H. Huskisson and R. M. Merrill

Sandia National Laboratories**

Albuquerque, New Mexico

\section{ABSTRACT}

2-(5-Cyanotetrazolato) pentaamminecobalt(III) perchlorate (CP) is an inorganic secondary explosive that has been developed for applications involving deflagration-to-detonation transition. Previously the primary explosives lead azide and lead styphnate had been used. Stability and compatibility studies with CP have been conducted for periods up to three years. By using the rate of formation of cobalt(II) as the prime stability measurement for $\mathrm{CP}$ no reaction above baseline has been observed at temperatures at or below $80^{\circ} \mathrm{C}$. At $120^{\circ} \mathrm{C}$, approximately $2.2 \%$ reaction has been measured after three years with the concentration approaching a constant value. With the typical materials of construction in low voltage detonators, no compatibility

* This work was supported by the U.S. Department of Energy (DOE) under contract DE-AC04-76-DP00789.

${ }^{\star *}$ A U.S. DOE facility. 


\section{DISCLAIMER}

This report was prepared as an account of work sponsored by an agency of the United States Government. Neither the United States Government nor any agency Thereof, nor any of their employees, makes any warranty, express or implied, or assumes any legal liability or responsibility for the accuracy, completeness, or usefulness of any information, apparatus, product, or process disclosed, or represents that its use would not infringe privately owned rights. Reference herein to any specific commercial product, process, or service by trade name, trademark, manufacturer, or otherwise does not necessarily constitute or imply its endorsement, recommendation, or favoring by the United States Government or any agency thereof. The views and opinions of authors expressed herein do not necessarily state or reflect those of the United States Government or any agency thereof. 


\section{DISCLAIMER}

Portions of this document may be illegible in electronic image products. Images are produced from the best available original document. 
problems with $C P$ have been found. Adhesives such as epoxies have also shown good compatibility characteristics with $\mathrm{CP}$. The only material tested thus far that exhibits potential compatibility problems with $\mathrm{CP}$ has been copper.

\section{INTRODUCTION}

Nearly all low voltage, hot wire initiated explosive devices in the past have used primary type explosives as the initiating charge. In most designs the initiating primary explosive has been lead azide or lead styphnate. Because of the safety hazards involved in using such materials a major effort has been made at Sandia National Laboratories to develop new explosive materials that have the hot wire, low voltage initiating properties of a primary explosive but which do not exhibit the safety problems associated with such materials.

A series of new explosive compounds based upon inorganic transition metal coordination compounds has been developed in this program (most of which were cobalt (III) perchlorate compounds $(1)$ ). In some cases the candidate materials possess the desirable safety properties such as impact insensitivity and low susceptibility to electrostatic initiation. But equally important, these materials can be initiated from a hot wire and. achieve detonation within the short distances (less than 7 millimeters) required for detonator designs.

The explosive 2-(5-cyanotetrazolato) pentaamminecobalt (III) perchlorate has heen the most promieing material developed for 
these designs. Figure 1 shows the structure for this material which has been given the acronym $\mathrm{CP}$.

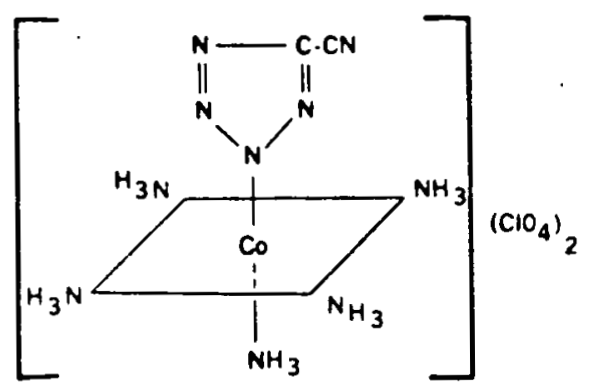

2-(5-Cyanotetrazolato) pentaaminecobalt(III) Perchlorate

Figure 1. Chemical structure and Name of CP

Numerous reports have been published on the preparation, properties and use of $C P$, some of which have been listed in Table $1^{(2-5)}$. Because of its desirable properties, CP has been committed for use in several low voltage, hot wire detonators at Sandia National Laboratories. This study was initiated to provide data on the stability and compatibility of $C P$ for use in long lived, high reliability explosive detonator designs. 
TABLE 1

PROPERTIES OF. $\mathrm{CP}(4,5)$

Molecular Weight:

Color:

Crystal structure:

Crystal Density:

Coefficient of Thermal

Expansion:

Heat Capacity:

Moisture Uptake at 95\% RH:

Impact Sensitivity:

Electrostatic Sensitivity:

Detonation Velocity:
$436.98 \mathrm{~g} / \mathrm{mol}$.

Yellow

Monoclinic

$1.974 \mathrm{Mg} / \mathrm{m}^{3}$ (x-ray diffraction)

$1.96 \mathrm{Mg} / \mathrm{m}^{3}$ (Helium Pycnometer)

$60 \times 10^{-6} \mathrm{~mm} / \mathrm{mm}^{\circ} \mathrm{K}\left(25\right.$ to $\left.50^{\circ} \mathrm{C}\right)$

$c_{p}\left(\frac{\mathrm{cal}}{\mathrm{g}^{\circ} \mathrm{K}}\right)=\begin{array}{r}0.1545+0.0003 \mathrm{~T}\left({ }^{\circ} \mathrm{K}\right) \\ \left(353-453^{\circ} \mathrm{K}\right)\end{array}$

$0.15 \mathrm{w} / 0$ at ambient temperature

$\sim 40 \mathrm{~cm}$ loose powder (2 kg weight)

Greater than $20 \mathrm{kV}$ at $600 \mathrm{pF}$ and 500 ohms (loose powder and unconfined pellet)

$D^{\star}\left(\frac{\mathrm{km}}{\mathrm{s}}\right)=0.868+3.608 \rho_{0}\left(\mathrm{Mg} / \mathrm{m}^{3}\right)$

CP STABILITY

Stability studies with CP have focused on three major areas of work. They are:

1. The stability of $\mathrm{CP}$ for use in long lived, high reliability components.

2. The effects of impurities and decomposition products on the decomposition of $C P$.

3. The effect of impurities and $C P$ decomposition products on the compatibility of $C P$ with other materials. 
Searcy and Shanahan ${ }^{(6)}$ have studied the thermal decomposition of CP at temperatures from $150^{\circ} \mathrm{C}$ to $260^{\circ} \mathrm{C}$ by a variety of techniques. Their work dealt with understanding the decomposition mechanisms of $\mathrm{CP}$ and the kinetics of decomposition in this temperature regime. They concluded that $\mathrm{CP}$ decomposition is a heterogeneous, solid-to-gas reaction that proceeds in three stages, with multiple and parallel paths ${ }^{(6)}$. They also concluded by extrapolation that $C P$ would be stable in the temperature range of ambient to $70^{\circ} \mathrm{C}$.

The decomposition mechanisms proposed by searcy and Shanahan may be summarized as follows ${ }^{(6)}$. Stage 1 is an endothermic process which includes the dissociation of ammonia ligands from the cobalt atom, rearrangement of the 5-cyanotetrazolato ligand to produce a nitrogen molecule and unidentified solid species, and the oxidation-reduction reaction of cobalt(III) with ammonia to produce cobalt(II), nitrogen and ammonium ion. Stage II is the oxidation of the ligands around the cobalt atom by the perchlorate ion. Stage III is the oxidation of the residual solid products by the perchlorate ion. Stability data have now been obtained with CP loaded components in the temperature range from ambient to $120^{\circ} \mathrm{C}$. Hermetically sealed CP loaded devices have been aged for periods up to three years. After aging, detonators were disassembled for examination by the scanning electron microscope and the CP removed for analysis. 
The amount of cobalt(II) formed during aging was established as the stability criterion for CP since cobalt(II) formation occurs during the first stage of decomposition. A spectrophotometric technique was developed to determine the concentration of cobalt(II) (7). The detection limits of this technique have been established at $100 \mathrm{ppm}$ cobalt(II) in the solid CP samples. However, due to the nature of the solvent system, sample sizes, instrumentation, and the nature of sample collection techniques, the accuracy of the method is limited to $500 \mathrm{ppm} \pm 200 \mathrm{ppm}$ cobalt (II) ${ }^{(7)}$.

Table 2 lists cobalt(II) analyses of CP from the detonator aging program. Even though cobalt(II) values of less than 500 ppm have been reported, these values are believed to be identical within experimental error. CP has shown no measurable decomposition at temperatures of $80^{\circ} \mathrm{C}$ or below for periods up to three years. At $120^{\circ} \mathrm{C}, \mathrm{CP}$ decomposes in less than 612 days and displays a fairly constant cobalt(II) concentration for time periods from 612 to 1078 days ( 3 years). Calculations involving the cobalt(II) concentration indicate that approximately 2.2\% of the CP has decomposed. One of the 1078 day ( 3 year), $60^{\circ} \mathrm{C}$ samples displayed an anomalous high cobalt(II) concentration (1370 ppm) which cannot be readily explained. This aging program has been continuing with the preliminary conclusion that no stability problems with CP are likely to exist in a detonator design for temperatures up to $80^{\circ} \mathrm{C}$ and three years. 
TABIE 2

$$
\begin{gathered}
\mathrm{Co}^{+2} \text { Analysis of CP Removed } \\
\text { from Aged Mini-Dets }
\end{gathered}
$$

\begin{tabular}{|c|c|c|c|}
\hline Environment & 612 Days & 795 Days & 1078 Days \\
\hline \multirow[t]{4}{*}{ Room Temp } & 166 & 301 & $456 \pm 215$ \\
\hline & 334 & 630 & $778 \pm 209$ \\
\hline & $<100$ & & \\
\hline & $<100$ & & \\
\hline \multirow[t]{3}{*}{$60^{\circ} \mathrm{C}$} & 254 & 383 & $639 \pm 169$ \\
\hline & $<100$ & 355 & $1370 \pm 134$ \\
\hline & 313 & & \\
\hline \multirow[t]{2}{*}{$80^{\circ} \mathrm{C}$} & 299 & 461 & $463 \pm 93$ \\
\hline & 824 & 542 & $839 \pm 171$ \\
\hline \multirow[t]{4}{*}{$120^{\circ} \mathrm{C}$} & 3710 & 3070 & $3160 \pm 218$ \\
\hline & 2270 & 4557 & $4180 \pm 138$ \\
\hline & 2700 & & \\
\hline & 3150 & & \\
\hline
\end{tabular}

$\underline{\text { PPM Co }}{ }^{+2}$ Present After Aging

A comparison of these data with that obtained from Searcy and Shanahan's low temperature extrapolation indicates general agreement. The results of the two studies show that the cobalt(II) concentration from CP decomposition should be below $800 \mathrm{ppm}$ at temperatures below $80^{\circ} \mathrm{C}$ and therefore not measurable. The average $C P$ decomposition of 2.28 from the 1078 day, $120^{\circ} \mathrm{C}$ aging was also in reasonable agreement with the $1.3 \%$ decomposition predicted by Searcy and Shanahan. 
Thermal analysis of $C P$ shows the three stage heterogeneous decomposition process. Figure 2 is a differential scanning calorimeter (DSC) trace for CP under two different sets of conditions; the sample used for curve $A$ was contained in a hermetically sealed minimum volume aluminum samplé cup whereas the CP sample for curve $B$ was in an open aluminum cup where the decomposition gases were swept away by a $100 \mathrm{~cm}^{3} \mathrm{~min}^{-1}$ argon purge gas. Curve A of Figure 2 shows the three stage decomposition process of CP starting with the weak endothermic response (Stage I) at about $270^{\circ} \mathrm{C}$, quickly followed by a broad exothermic response (Stage II) and ending with a sharp second exothermic response (Stage III). Much of the magnitude of the endothermic response has been masked by the dominant, more energetic first exothermic response (Stage II). Curve B of Figure 2 shows the initial endothermic response as in curve A but only one exotherm. In addition both the endothermic and exothermic responses have been shifted to lower temperatures in the open environment.

Since ammonia $\left(\mathrm{NH}_{3}\right)$ plus other reaction products were part of the first stage of CP decomposition, it was felt that one of the decomposition products, particularly ammonia, could be inhibiting the decomposition reaction in the sealed environment ${ }^{(8)}$. Further work by Reed has established that the presence of excess gaseous ammonia shifts the decomposition reaction of $C P$ to a higher temperature ${ }^{(9)}$. For example the DSC exotherm was shifted some 20 to $30^{\circ} \mathrm{C}$ upwards while isothermal thermogravimetry at $235^{\circ} \mathrm{C}$ shifted the decomposition time from 50 minutes to more than 100 minutes. 


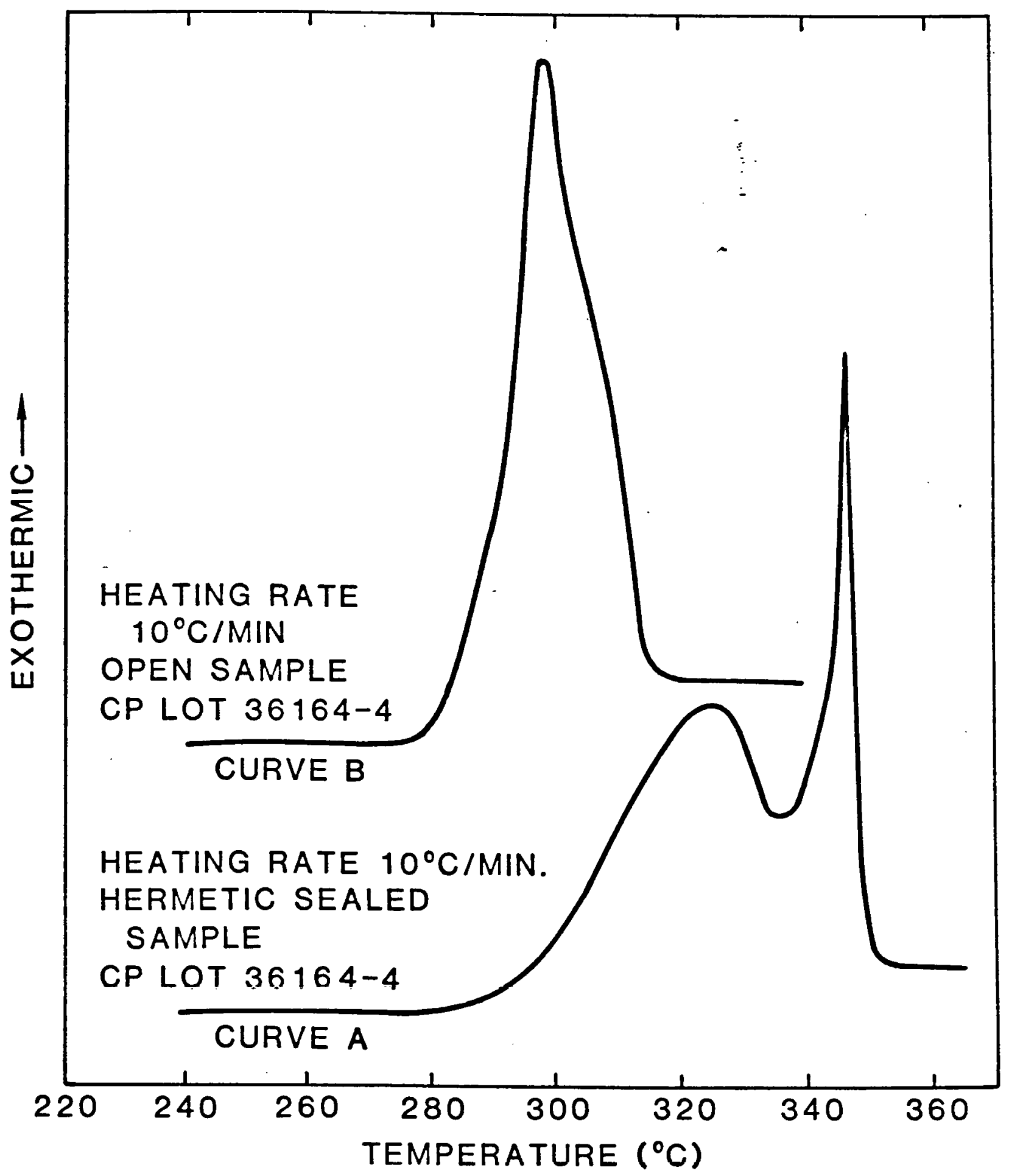

FIGURE 2

CP DSC THERMAL ANALYSIS CURVES

HERMETICALLY SEALED SAMPLE

VERSUS

OPEN SAMPLE 
Two thermal analysis procedures were used to determine the effects of impurities and reaction products on the decomposition of $\mathrm{CP}$. The first procedure was based upon a first order reaction of a solid to a solid plus gas under nonisothermal conditions using the equation derived by Kissinger $(10-12)$. The basic equation was:

$$
\frac{\mathrm{d} \ell n\left(\phi / \mathrm{Tm}^{2}\right)}{\mathrm{d}(1 / \mathrm{Tm})}=-\frac{\mathrm{E}_{\mathrm{A}}}{\mathrm{R}}
$$

where

$$
\begin{aligned}
\Phi= & \text { heating rate } \\
\mathrm{Tm}= & \text { temperature maximum or peak temperature of } \\
& \text { the DTA or DSC exotherm, } \\
\mathrm{E}_{\mathrm{A}}= & \text { Arrhenius activation energy, and } \\
\mathrm{R}= & \text { universal gas constant. }
\end{aligned}
$$

For a first order reaction, a plot of $\ln \left(\phi / \mathrm{Tm}^{2}\right)$ versus $1 / \mathrm{Tm}$ will yield the Arrhenius activation energy. The temperature shifts in the peaks were obtained by running the DSC at various heating rates (Figure 3). Both open and hermetically sealed samples were investigated.

The second procedure was an isothermal technique which employs a Dupont 990 Thermal Analysis system and utilizes a modified procedure after the one developed by Rogers for organic explosive materials(13). The $C P$ sample was loaded into an open cup configuration and placed in an isothermally stabilized DSC cell. The time to peak of the decomposition curve (Figure 4) was plotted against the reciprocal of the absolute isothermal temperature in a typical Arrhenius plot. Figure 5 shows plots 


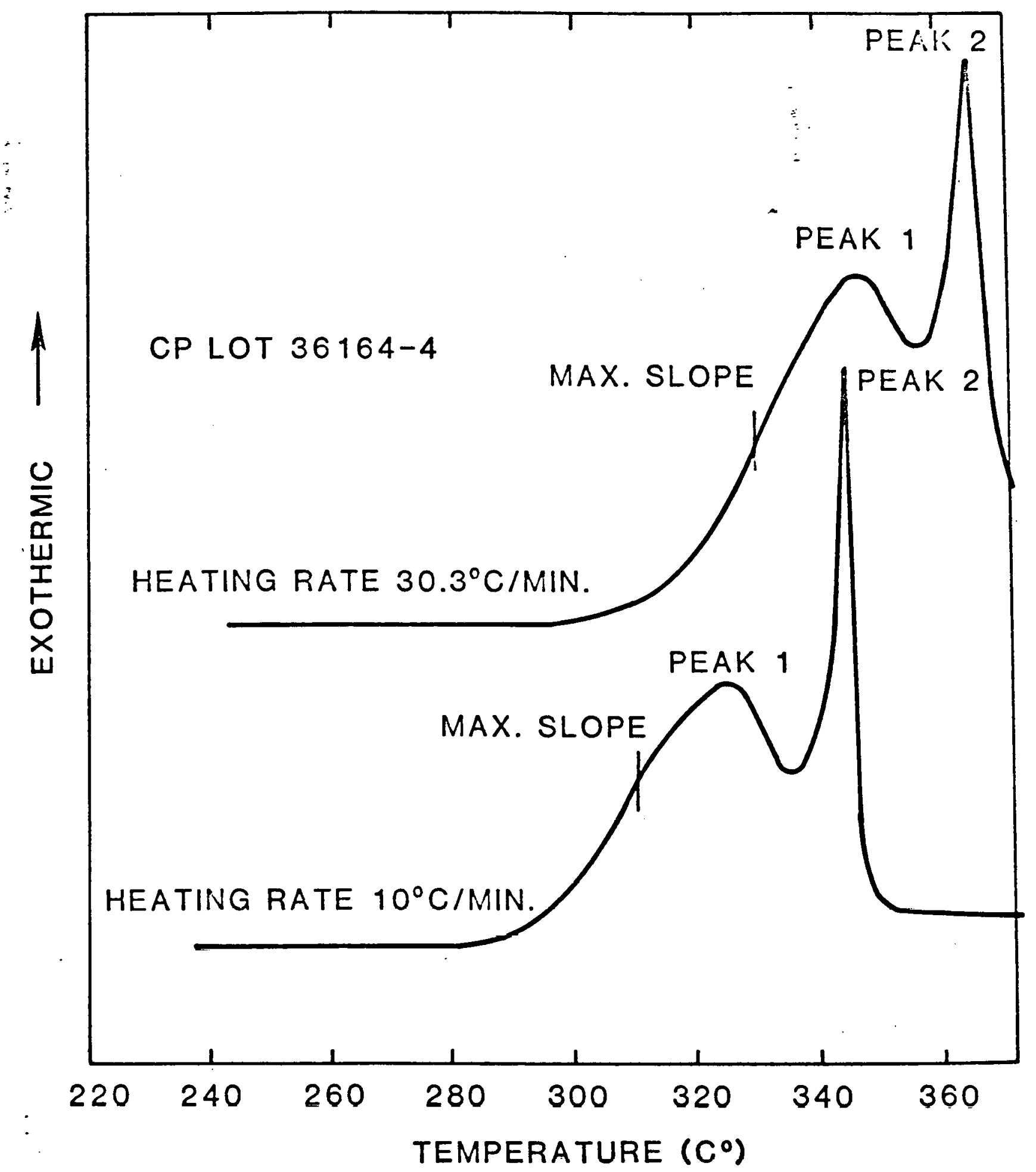

FIGURE 3

SHIFT IN DSC EXOTHERM OF CP WITH HEATING RATE (HERMETICALLY SEALED SAMPLE) 


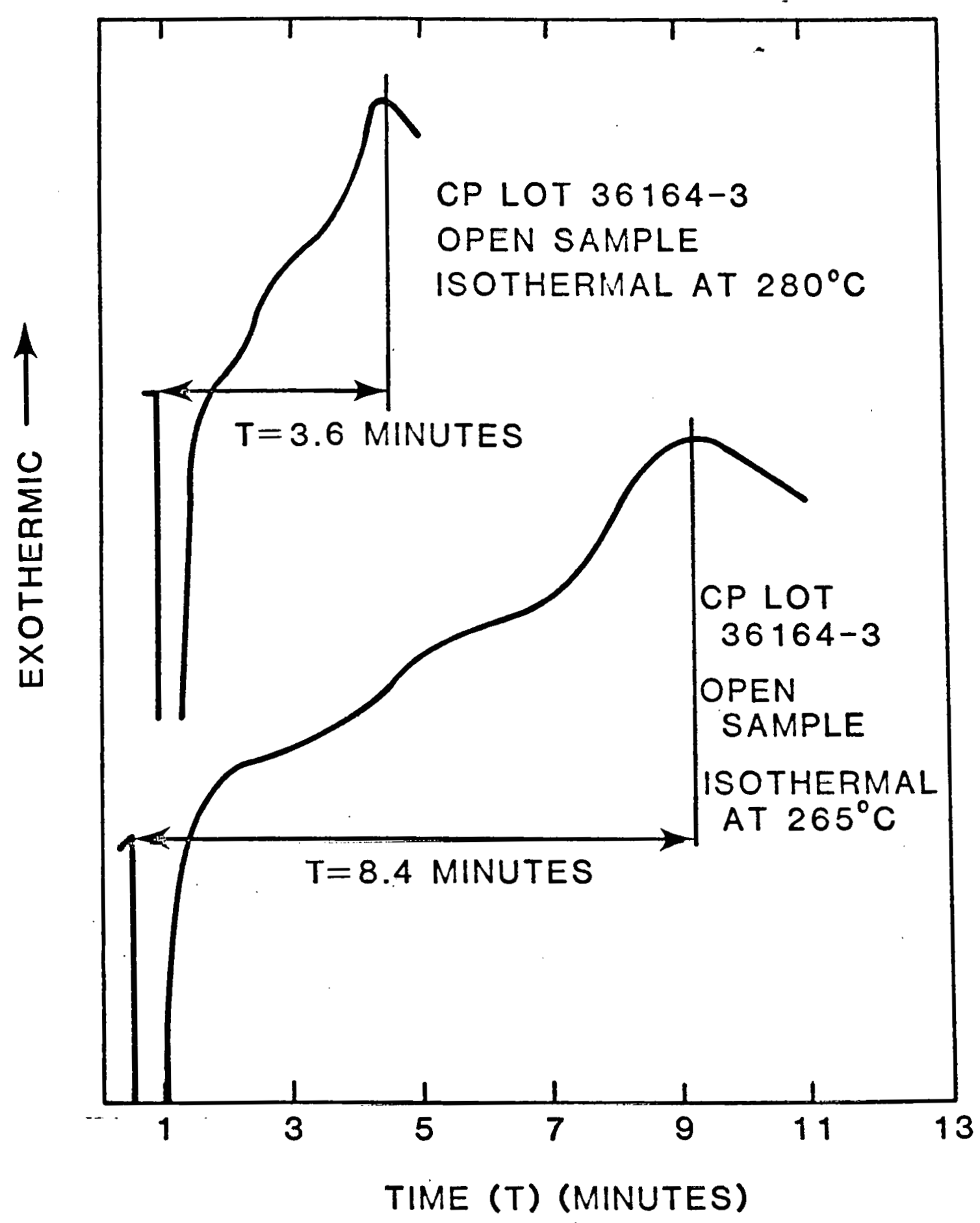

FIGURE 4

ISOTHERMAL ANALYSIS OF CP 


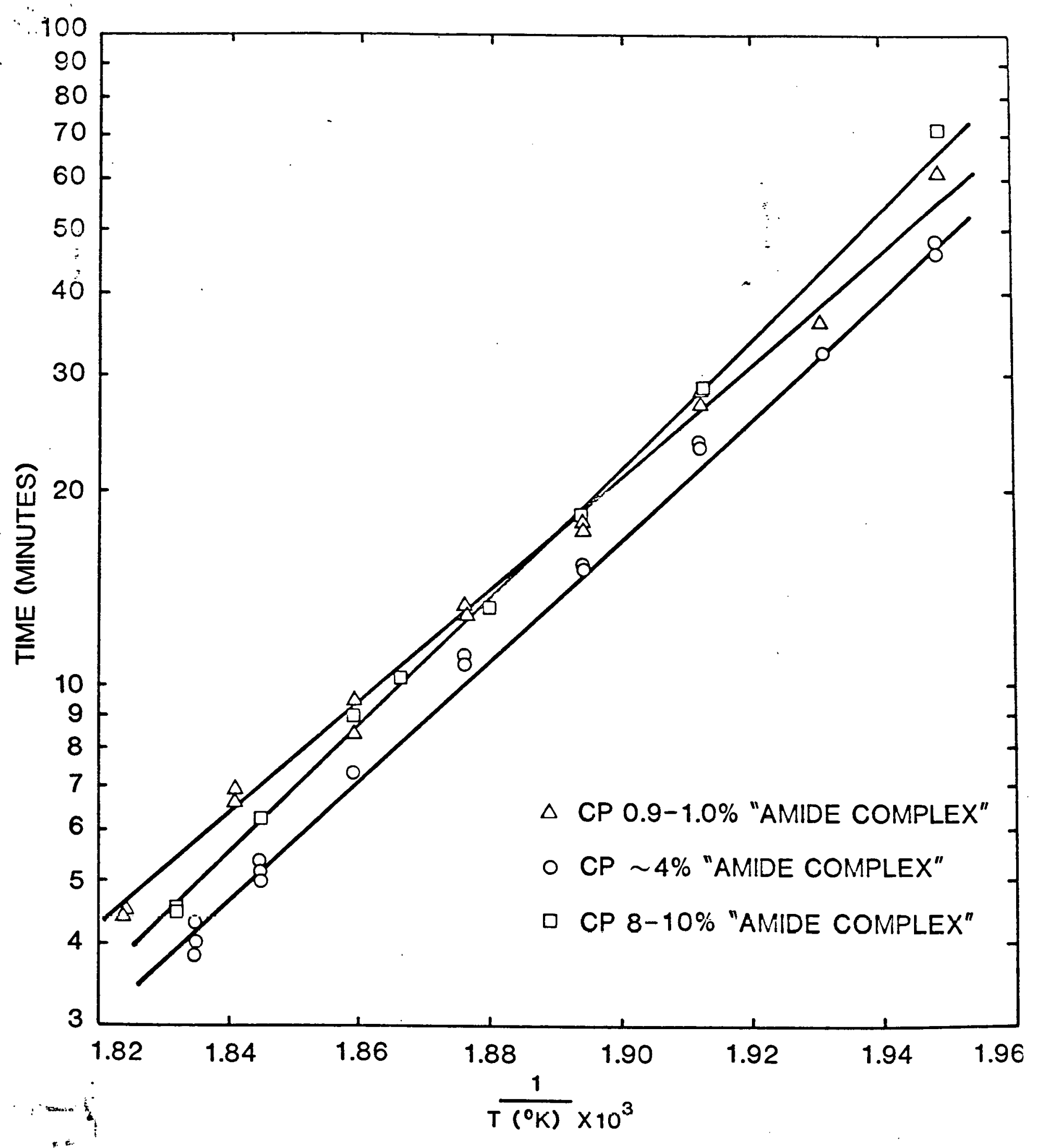

FIGURE 5

ISOTHERMAL KINETIC DSC

ANALYSIS OF CP

EFFECT OF "AMIDE COMPLEX"

CONCENTRATION 
for three different lots of CP. As will be discussed later, this technique has been used as a screening procedure for CP compatibility.

During the preparation of $\mathrm{CP}$, significant amounts of the impurity 5-carboxamidotetrazolatopentaamminecobalt (III) perchlorate (called the "amide complex") (Figure 6) have been obtained. Having a chemical structure and solubility properties similar to $\mathrm{CP}$, amounts up to 10 percent have been found. By using the above thermal analysis techniques, no effect on the activation energy or shifts in the temperature (or rate) could be found for various $C P$ lots containing varying amounts of the "amide complex" from one (1) to ten (10) percent. Tables 3 and 4 show no significant variations in the activation energy as a function of the "amide complex" concentration. These activation energies have a precision of $\pm 3 \mathrm{kcal} / \mathrm{mol}$. Figure 5 shows the Arrhenius plots for the three lots of $C P$ with varying amide complex concentrations showing no shift in the curves which indicate no autocatalysis or inhibition of the decomposition reaction.



Figure 6. Proposed Chemical structure of the "Amide Complex" 
TABLE 3

\author{
Activation Energy (kcal/mol) of CP \\ with Varying Amounts of the "Amide Complex" \\ (Non-Isothermal Method-Hermetically Sealed Sample)
}

\begin{tabular}{|c|c|c|c|}
\hline \multirow[b]{2}{*}{ Exothermic Response } & \multicolumn{3}{|c|}{ Sample } \\
\hline & $\begin{array}{r}\text { Lot } 36353 \mathrm{~A} \\
0.9-1.0 \% \\
\text { "Amide Complex" } \\
\end{array}$ & $\begin{array}{c}\text { Lot } 47344 \\
\sim 4 \% \\
\text { "Amide Complex" }\end{array}$ & $\begin{array}{r}\text { Lot } 36164 \\
8-10 \% \\
\text { "Amide Complex" }\end{array}$ \\
\hline $\begin{array}{l}\text { Maximum Slope } \\
\text { (lst exotherm) }\end{array}$ & 27.4 & 31.3 & 27.9 \\
\hline $\begin{array}{l}\text { Peak Maximum } \\
\text { (lst exotherm) }\end{array}$ & 29.8 & 32.2 & 32.3 \\
\hline $\begin{array}{l}\text { Peak Maximum } \\
\text { (2nd exotherm) }\end{array}$ & 34.4 & 43.7 & 42.1 \\
\hline
\end{tabular}

\title{
TABLE 4
}

Activation Energy (kcal/mol) of $\mathrm{CP}$

with Varying Amounts of the "Amide Complex"

(Open Sample)

\begin{tabular}{|c|c|c|c|}
\hline & & Sample & \\
\hline & $\begin{array}{c}\text { Lot } 36353 \mathrm{~A} \\
9.9-1.08 \\
\text { "Amide Complex" }\end{array}$ & $\begin{array}{c}\text { Lot } 47344 \\
\sim 4 \% \\
\text { "Amide Complex" }\end{array}$ & $\begin{array}{c}\text { Lot } 36164 \\
8-10 \% \\
\text { "Amide Complex" }\end{array}$ \\
\hline Non-Isothermal Method & 44.4 & 49.6 & 39.2 \\
\hline Isothermal Method & 13.4 & 42.9 & 41.7 \\
\hline
\end{tabular}


In a similar manner, both procedures were used to examine any similar effects of the decomposition products on CP. Tables 5 and 6 list the activation energies obtained for the aged $C P$ powders. Again the precision was $\pm 3 \mathrm{kcal} / \mathrm{mol}$.

TABLE 5

Activation Energy (kcal/mol) of $\mathrm{CP}$

from Aged Detonators

(Non-Isothermal Method - Hermetically Sealed Sample)

\begin{tabular}{|c|c|c|c|c|c|c|c|c|}
\hline \multirow[b]{3}{*}{ Exothermic Response } & \multicolumn{8}{|c|}{ CP Sample } \\
\hline & & 612 & Days & & & 1078 & Days & \\
\hline & Amb. & $60^{\circ} \mathrm{C}$ & $80^{\circ} \mathrm{C}$ & $120^{\circ} \mathrm{C}$ & Amb. & $60^{\circ} \mathrm{C}$ & $80^{\circ} \mathrm{C}$ & $120^{\circ} \mathrm{C}$ \\
\hline $\begin{array}{l}\text { Maximum Slope } \\
\text { (Ist exotherm) }\end{array}$ & 31.7 & 30.8 & 31.5 & 32.4 & 30.8 & 35.1 & 30.1 & 32.5 \\
\hline $\begin{array}{l}\text { Peak Maximum } \\
\text { (lst exotherm) }\end{array}$ & 32.7 & 32.6 & 31.5 & 33.6 & 30.5 & 30.7 & 34.8 & 38.4 \\
\hline $\begin{array}{l}\text { Peak Maximum } \\
\text { (2nd exotherm) }\end{array}$ & 45.6 & 44.8 & 42.3 & 40.9 & 48.7 & 39.7 & 44.4 & 46.8 \\
\hline
\end{tabular}

TABIE 6

Activation Energy (kcal/mol) of CP

from Aged Detonators

(Isothermal Method - Open Sample)

Sample

\begin{tabular}{|c|c|c|c|}
\hline $\begin{array}{c}C P \\
\text { Unaged }\end{array}$ & $\begin{array}{c}\mathrm{CP} \\
60^{\circ} \mathrm{C}\end{array}$ & $\begin{array}{c}C P \\
80^{\circ} \mathrm{C}\end{array}$ & $\begin{array}{c}\mathrm{CP} \\
120^{\circ} \mathrm{C}\end{array}$ \\
\hline Powder & 812 Days & 812 Days & 812 Days \\
\hline 42.9 & 42.5 & 42.4 & 42.4 \\
\hline
\end{tabular}


Figure 7 shows the Arrhenius plot for the isothermal experiments on the aged samples. No variation in the activation energy or shifts in the Arrhenius plots could be found, even for the $120^{\circ} \mathrm{C}$ aged $\mathrm{CP}$ containing $2.2 \%$ decomposition products. The data listed in Tables 4 and 6 are a combination of the activation energies from all the competing reactions taking place in one single exothermic response whereas the data in Tables 3 and 5 are activation energies of two separate reaction steps. Therefore these data are not expected to be comparable. The variation in activation energies between the first and second exothermic responses in Tables 3 and 5 are consistent with the findings by searcy and shanahan.

From these results, it can be concluded that the solid decomposition products and impurities in this study have no apparent autocatalytic or inhibitive effect on the CP decomposition. Gaseous decomposition products such as ammonia inhibit the decomposition by shifting the reactions to higher temperatures.

CP COMPATIBILITY

In addition to being stable a new detonator material must also demonstrate compatibility with the environment around it. For our applications the material must be compatible with design materials, especially the detonator bridgewire, electrode pins and weld interface. 


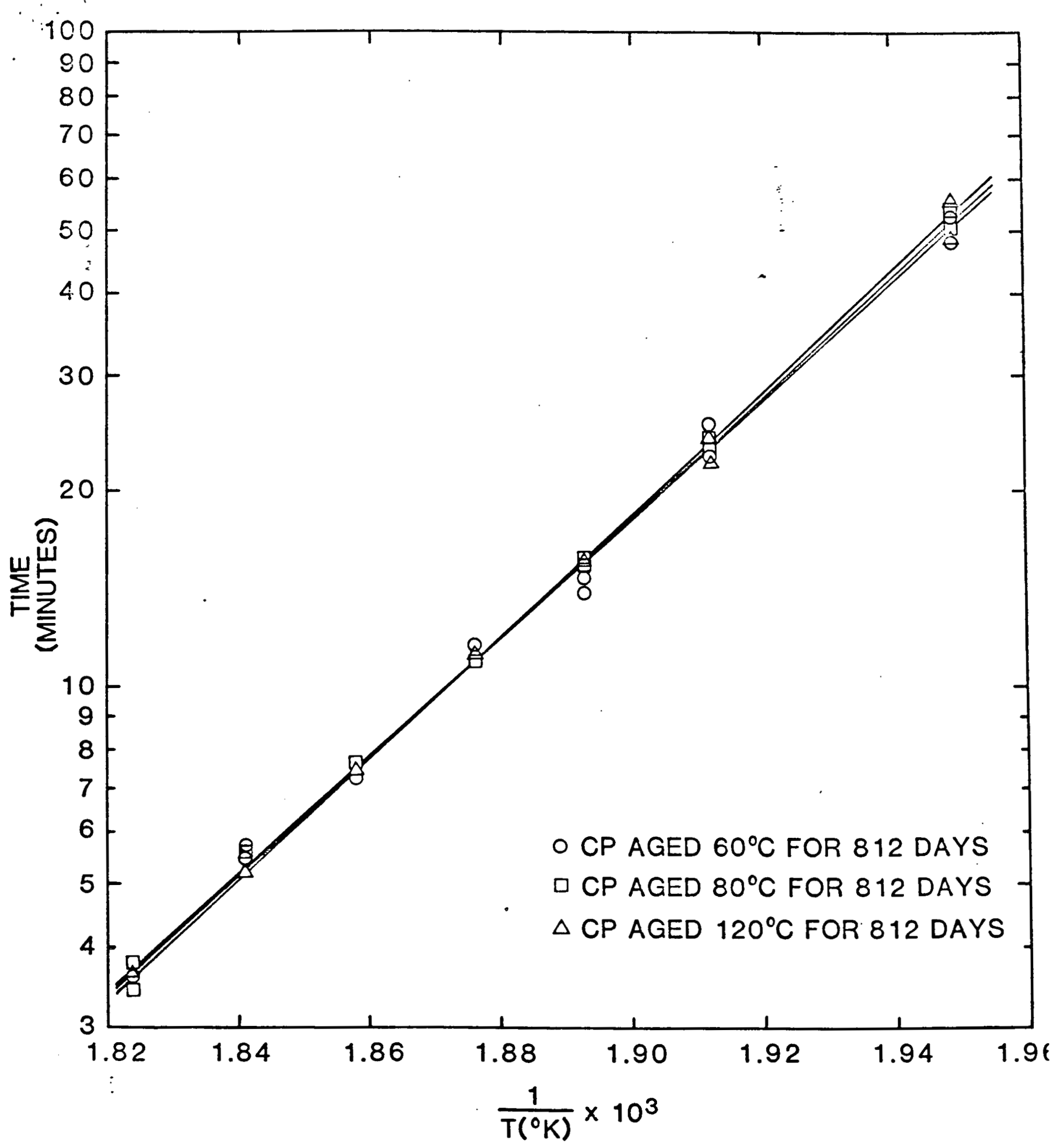

FIGURE 7

ISOTHERMAL KINETIC DSC

ANALYSIS OF CP

EFFECT OF DECOMPOSITION PRODUCTS 
Various decomposition products can be produced from $\mathrm{CP}$ such as ammonia and water plus ammonium $\left(\mathrm{NH}_{4}^{+}\right)$, chloride $\left(\mathrm{Cl}^{-}\right)$ and cyanide $\left(\mathrm{CN}^{-}\right)$ions. For thermally reacted samples all of the above have been found to be present in CP. With other energetic materials some of these species have been known to cause corrosion directly or indirectly of metallic materials. Impurities from the CP synthesis steps such as nitrate $\left(\mathrm{NO}_{3}^{-}\right)$and perchlorate $\left(\mathrm{ClO}_{4}^{-}\right)$ions can also be present and lead to compatibility problems.

The primary technique used to evaluate the compatibility of these materials with CP has been scanning electron microscopy (SEM) which can readily detect the presence of corrosion or reaction products on the various materials. Scanning electron microscopy has been previously used to evaluate compatibility of pyrotechnic materials with component design materials and has been successful in the detection and monitoring of corrosion which occurred in these designs $(14,15)$.

Detonator housings with the CP removed for cobalt(II) analyses were examined for corrosion and other compatibility problems with the scanning electron microscope. No evidence of corrosion or reactions taking place were observed for periods up to three years and temperatures from ambient to $120^{\circ} \mathrm{C}$ for any of the materials listed in Table 7 .

Figures 8 and 9 are typical SEM photomicrographs of the electrode pin and bridgewire surfaces, respectively, after three years aging at $120^{\circ} \mathrm{C}$. No compatibility problems were observed, 


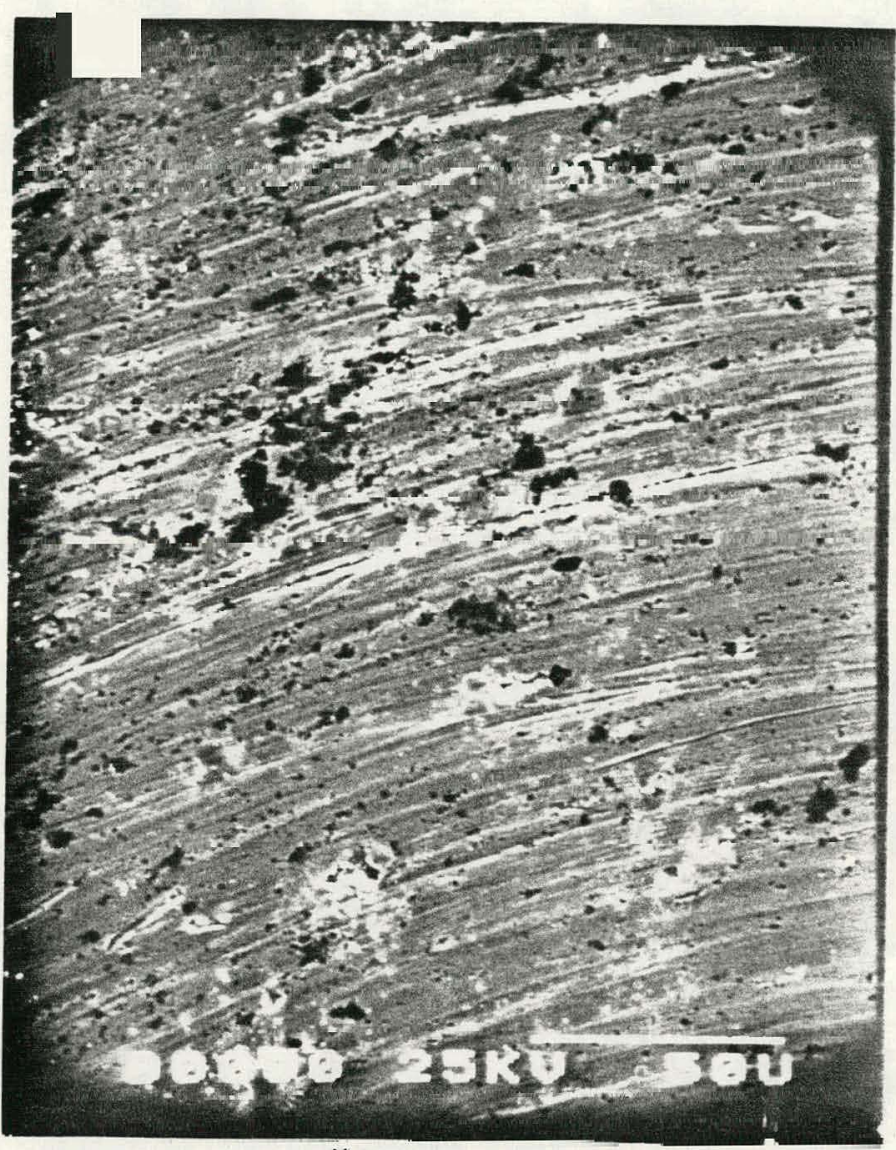

$60^{\circ} \mathrm{C} / 1 \mathrm{C} 78$ DAYS

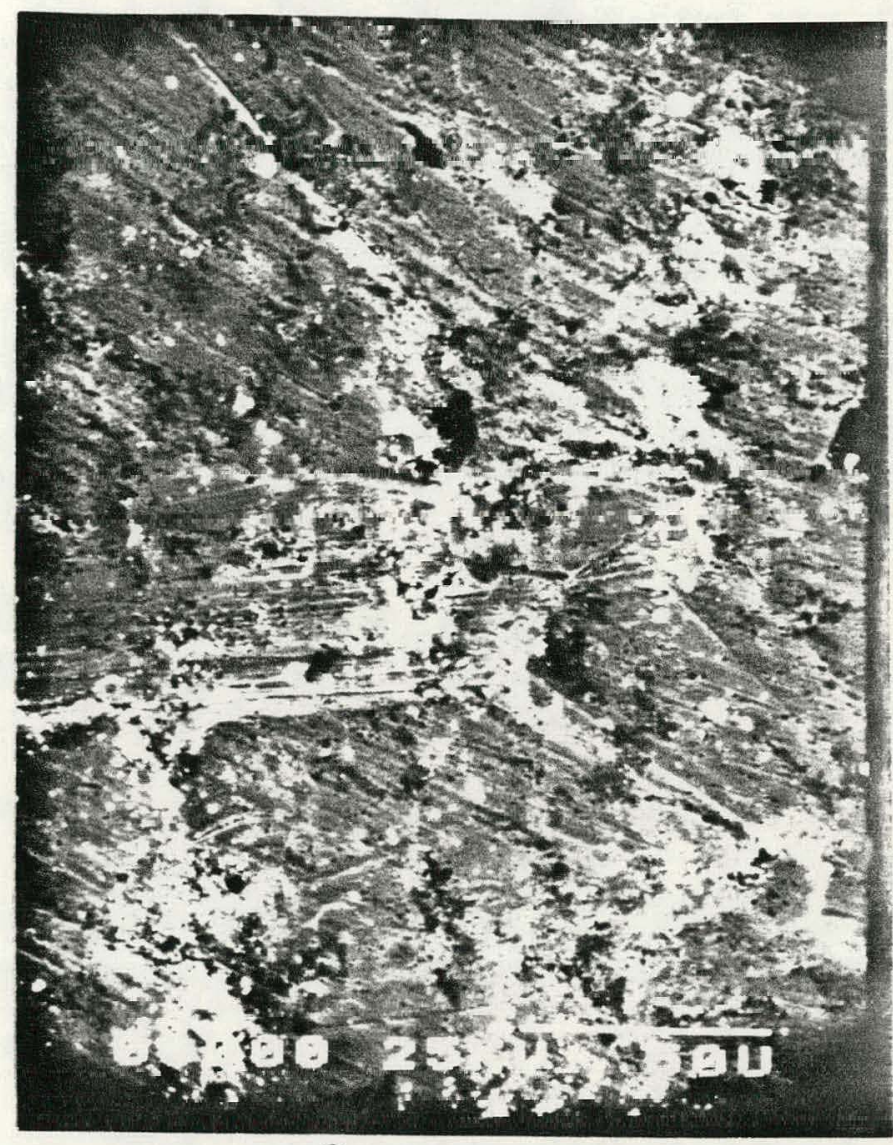

$120^{\circ} \mathrm{C} / 1073$ DAYS

FIGURE 3

SEIT PHCTOIIICROGRAPIIS

OF KOVAR PINS Iii

CONTACT HITH CP 

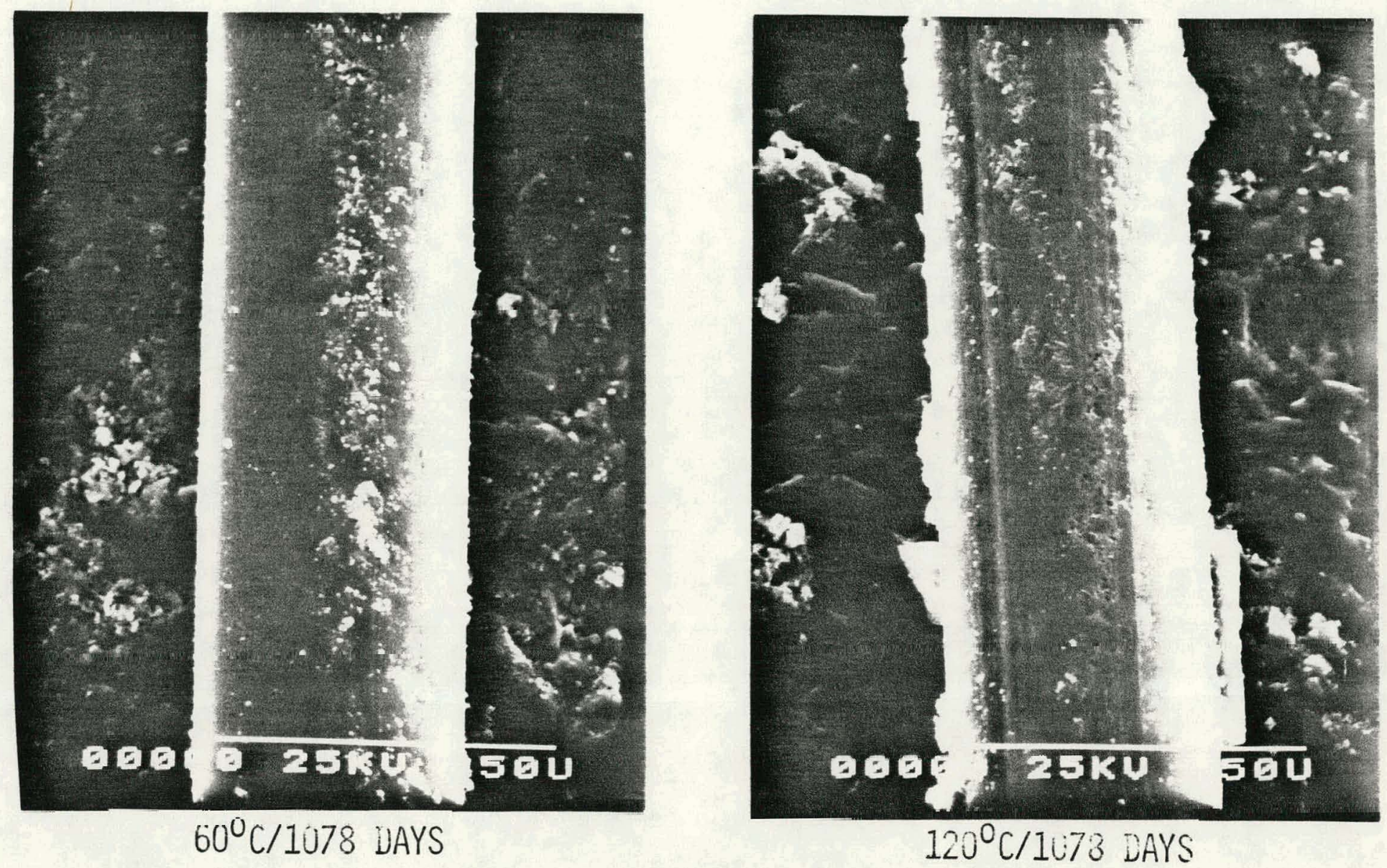

FIGURE S

SEN PHOTOMICROGRAPHS

OF TOPHET A BRIDGEHIRES

IN COITACT NITH CP 
although significant reaction of the CP powder had occurred for the $120^{\circ} \mathrm{C}$ samples resulting in potentially active decomposition products.

\section{TABLE 7}

Detonator Design Materials

Employed in Compatibility Evaluations

1. Bridgewire: Tophet A (Nichrome alloy)

2. Electrode Pins: Kovar

3. Weld Junction: Laser weld of the Tophet $A$ and Kovar

4. Metallizing: Molybdenum/Nickel oxide

5. Ceramic Braze: Silver

6. Ceramic Insulator: Diamonite (95\%)

7. Detonator Housing and Closure Disk: Stainless Steel 304

Other compatibility studies with $\mathrm{CP}$ have also been conducted. $\mathrm{CP}$ mixed with the pyrotechnic boron/calcium chromate ( $\left.\mathrm{B} / \mathrm{CaCrO}{ }_{4}\right)$ and pressed with Tophet $A$ and Kovar wires have shown no compatibility problems of the wire materials after eight (8) months jging at ambient 50 and 92 percent relative humidities and thermal environments up to $120^{\circ} \mathrm{C}$. No reaction between the calcium chromate and $C P$ has been observed for thermally aged samples up to $120^{\circ} \mathrm{C}$ or the ambient and 50 percent relative humidity samples. At 92 percent relative humidity, a few small (5 microns or less) crystals of the chromate analog of $\mathrm{CP}$ were identified within the mixture after eight (8) months aging. 
Solution chemistry experiments with $\mathrm{CP}$ and chromate $\left(\mathrm{CrO}_{4}^{2-}\right.$ ) ions dissolved in water predicted this result for high humidity conditions because a compound, inferred to be the chromate analog of CP precipitated stoichiometrically. Under normal humidity conditions (50 percent or less) and thermal environments, none of the chromate analog has been found.

The main screening technique for determining the compatibility of CP with other materials has been the isothermal DSC procedure previously described in the stability section. Figure 10 shows typical reaction rate plots for Arrhenius activation energy of copper powder mixed with CP, alumina mixed with $C P$ and $C P$. No variations were observed in the activation energy reaction rate curves for the alumina mixed with CP compared to $C P$ alone. For the copper mixed with $C P$ sample a significant increase in the decomposition rate compared to $C P$ was observed along with a decrease in the activation energy (Table 8). Follow-up studies utilizing copper wires pressed against $C P$ powder have resulted in some corrosion of the copper wire when subjected to a $120^{\circ} \mathrm{C}$ environment. Cobalt(II) analysis of equal mixtures of $C P$ and copper powder which had been aged for two days at $120^{\circ} \mathrm{C}$ yielded values 3 to 4 times above pure $C P$ similarly aged. $C P$ has been found to be incompatible with copper and should not be considered for designs which contain copper. $C P$ is considered compatible with alumina. Amine and anhydride cured epoxy materials in the cured and uncured conditions have shown no compatibility problems with $C P$. 




FIGURE 10

ISOTHERMAL KINETIC DSC

ANALYSIS OF CP

COMPATIBILITY STUDIES 
This is in contrast with organic explosives and amine cured epoxy materials where numerous compatibility problems exist. The primary short term test for compatibility of CP with adhesives has been the chemical reactivity test (CRT) which measures the type and quantity of evolved gases due to reaction between the materials in question. Follow-up studies of these epoxy materials with CP for periods up to four months and temperatures up to $120^{\circ} \mathrm{C}$ have also revealed no compatibility problems occurring. Currently all uses of epoxy materials with CP have lifetime requirements of four months or less; therefore, no long term data have been generated.

TABLE 8

Activation Energy of CP Compatibility Samples

Activation Energy ( $\mathrm{kcal} / \mathrm{mol})$

CP Lot 36164

CP Lot 47344

CP plus Alumina

(50/50 $\mathrm{mix}$ )

CP plus Copper (50/50 mix)
41.7

42.9

41.1

34.7 


\section{CONCLUSIONS}

Based upon the above data the following conclusions pertaining to $C P$ stability and compatibility have been drawn.

1. $\mathrm{CP}$ has been shown to be thermally stable up to temperatures of $80^{\circ} \mathrm{C}$ for three years.

2. $\mathrm{CP}$.will undergo decomposition at $120^{\circ} \mathrm{C}$.

3. Impurities and decomposition products in $C P$ do not affect its decomposition.

4. Gaseous decomposition products such as ammonia shift the decomposition of CP to higher temperatures.

5. $C P$ has been found compatible with most metallic, ceramic and epoxy materials used in typical detonator designs.

6. $C P$ has been found incompatible with copper.

7. The isothermal DSC technique described has been shown to be a useful screening technique for compatibility testing of $\mathrm{CP}$. It cannot be used to determine compatibility with materials that decompose at temperatures below the decomposition temperature of CP. 


\section{REFERENCES}

1. Unpublished work at both Sandia National Laboratories (M. L. Lieberman) and Unidynamics/Phoenix, Inc. (J. W. Fronabarger).

2. W. B. Leslie, R. W. Dietzel and J. Q. Searcy, "A New Explosive for Low Voltage Detonator Application," in the Proceedings of the 6th International Symposium on Detonation, San Diego, CA, August 1976.

3. W. Fleming, J. W. Fronabarger and J. Q. Searcy, "Preparation of 2-(5-Cyanotetrazolato) pentaamminecobalt (III) Perchlorate, $C P$, a New Material for Detonator Applications," in the Proceedings of the American Defense Preparedness Association, Materials and Processing Division, Albuquerque, NM, May 15-17, 1979 .

4. M. L. Lieberman and J. W. Fronabarger, "An Overview of the Development of the Explosive 2-(5-Cyanotetrazolato) pentaamminecobalt(III) Perchlorate," presented at the ACS/CJS Chemical Congress, Honolulu, HI, April 1-6, 1979.

5. M. L. Lieberman, Sandia National Laboratories, and J. W. Fronabarger, Unidynamics/Phoenix, Inc., "Status of the Development of 2-(5-Cyanotetrazolato) pentaamminecobalt (III) Perchlorate for DDT Devices," Proceedings of the $7 \mathrm{th}$ International Pyrotechnics Seminar, hosted by IIT Research Institute, Vail, CO, July 14-18, 1980, pp 322-55.

6. J. Q. Searcy and K. L. Shanahan, "Thermal Decomposition of the New Explosive 2-(5-Cyanotetrazolato) pentaamminecobalt (III) Perchlorate," SAND78-0466, Sandia Laboratories, August 1978.

7. R. M. Merrill, "Spectrophotometric Determination of Co(II) in the Presence of the Coordination Compound, 2-5-Cyanotetrazolato-pentaamminecobalt(III) Perchlorate (CP)," SAND79-0653, Sandia Laboratories, unpublished.

8. M. L. Lieberman, editor, "The Deflagration-to-Detonation Transition Project: Quarterly Report for the Period December 1978 through February 1979," SAND79-1267, Sandia Laboratories, 1979.

9. M. L. Lieberman, editor, "The Deflagration-to-Detonation Transition Project: Quarterly Report for the Period December 1979 through February 1980," SAND80-1862, Sandia Laboratories, in progress.

10. H. E. Kissinger, J. Res. Nat. Bur. Standards, 57(1956) 217. 
11. H. E. Kissinger, Anal. Chem. 29(1957) 1702.

12. Joel Harris, Thermochimica Acta 14(1976) 183.

13. R. N. Rogers, Thermochimica Acta, $\underline{3}$ (1972) 437.

14. J. T. Healey, R. E. Whan and T. M. Massis, "Corrosion Mechanisms in Pyrotechnic Devices Containing T̂Titanium/ Potassium Perchlorate," in Proceedings of the 7 th Annual DOE Compatibility Meeting, Aiken, SC, October 16-18, 1979.

15. D. H. Huskisson, T. M. Massis and J. T. Healey, "Morphological Changes in $\mathrm{KClO}_{4}$ : A Sensitive Indicator of Potential Corrosion Problems in $\mathrm{TI} / \mathrm{KClO}_{4}$ Loaded Devices," in the Proceedings, American Defense Preparedness Association, Compatibility Division, Albuquerque, NM, May 15-17, 1979. 